\title{
PELAKSANAAN SERTIFIKASI TANAH WAKAF DI KALIMANTAN TIMUR
}

\author{
Yatini \\ Dosen Fakultas Hukum Universitas Widya Gama Mahakam Samarinda
}

\begin{abstract}
ABSTRAK
Telah dilakukan penelitian tentang Pelaksanaan Sertifikasi Tanah wakaf di Kalimantan Timur, setelah diundangkannya Undang-Undang Nomor 41 Tahun 2004 tentang Wakaf. Penelitian ini dilakukan untuk mendeskripsikan secara detail dari pelaksanaan sertifikasi tanah wakaf di Kalimantan Timur, juga menjelaskan tentang kendala-kendala yang menjadi hambatan pelaksanaan sertifikasi tanah wakaf serta upaya-upaya yang dilakukan dalam menghadapi hambatan-hambatan pelaksanaan sertifikasi tanah wakaf. Jenis penelitian yang digunakan adalah deskriptif kualitatif, dengan metode penelitian lapangan dalam pengumpulan data dengan wawancara dan dokumentasi. Subyek penelitian meliputi Kepala Kantor Wilayah Kementerian Agama Provinsi Kalimantan Timur, Kepala Kantor Kementerian Agama Kota Samarinda, Kepala Kantor Pertanahan Kota Samarinda, Kepala Kantor Kementerian Agama Kota Balikpapan, Kepala Kantor Pertanahan Kota Balikpapan, Kepala Kantor Kementerian Agama Kabupaten Kutai Kartanegara, Kepala Kantor Badan Pertanahan Kabupaten Kutai Kartanegara. Setelah pengolahan data maka hasil analisa menunjukkan bahwa jumlah tanah wakaf yang terdaftar di Kantor Wilayah Kementerian Agama Provinsi Kalimantan Timur sejumlah 1676, yang sudah bersertifikat sejumlah 899 dan yang belum bersertifikat sejumlah 777, yang menandakan bahwa pelaksanaan sertifikasi tanah wakaf di Kalimantan Timur belum maksimal karena tanah wakaf yang terdaftar di Kementerian Agama belum kesemuanya bersertifikat. Kendala-kendala dalam pelaksanaan sertifikasi tanah wakaf di Kalimantan Timur adalah pada proses sertifikasi di Kantor Pertanahan, belum efektifnya Surat Keputusan Bersama Menag. RI dan KBPN No. 422/2004 dan No. 3/SKB/BPN/2004 tanggal 19 Oktober 2004, biaya sertifikasi tanah wakaf yang diberikan oleh pemerintah masih terbatas, kurangnya pemahaman masyarakat terhadap wakaf, pengelolaan Badan Wakaf Indonesia (BWI) yang belum maksimal. Upaya-upaya yang dilakukan dalam menyelesaikan kendala-kendala sertifikasi tanah wakaf, adalah dengan menjalin pendekatan emosional dengan pihak Kantor Pertanahan, mengalokasikan anggaran untuk sertifikasi tanah wakaf, mengefektifkan peranan nadzir dalam pengelolaan wakaf, menumbuhkan wakaf produktif.
\end{abstract}

Kata Kunci: Tanah Wakaf, Sertifikat.

\section{PENDAHULUAN}

Harta benda wakaf tidak bergerak berupa tanah adalah jenis benda wakaf yang paling tua dibandingkan jenis benda lainnya. Pelaksanaan jenis wakaf ini didasarkan atas pertanyaan Umar bin Khattab terkait sebidang tanah subur miliknya di Khaibar, Madinah kepada Nabi saw. Nabi memberikan saran kepada Umar: jika engkau suka, tahan pokoknya, kelola, dan sedekahkan surplus-nya. Peristiwa tersebut kemudian dijadikan salah satu dalil favorit atas disyariatkannya wakaf dalam Islam, selain beberapa ayat Al Quran terkait, seperti QS: Ali Imran: 92, QS: Al Baqarah: 261, QS: Al Hajj: 77, dan lain-lain. ${ }^{1}$ 
Dalam konteks Indonesia, wakaf tanah telah diatur oleh Peraturan Pemerintah Nomor 28 Tahun 1977 tentang Perwakafan Tanah Milik dan Peraturan Menteri Agama Nomor 1 Tahun 1978 tentang Peraturan Pelaksanaannya. Dalam Undang-Undang Nomor 5 Tahun 1960 tentang Peraturan Dasar Pokok-Pokok Agraria (UUPA), secara tidak langsung wakaf tanah disebut dalam satu bagian tentang hak-hak tanah untuk keperluan suci dan sosial, meskipun tidak secara detail. Kemudian, sejak tahun 2004, peraturan perundang-undangan wakaf disempurnakan lagi melalui Undang-Undang Nomor 41 Tahun 2004 tentang Wakaf dan peraturan perundangan turunannya.

Paparan di atas menunjukkan, betapa wakaf tanah telah mendapat perhatian serius dalam sistem perwakafan dalam Islam, dan hukum positif negeri ini. Hal ini dapat dipahami karena jenis wakaf tanah tergolong fix asset yang memiliki nilai strategis dalam kehidupan umat manusia yang memiliki sandaran teologis dalam sistem keyakinan Islam.

Perwakafan dan sertifikasi tanah wakaf ternyata merupakan kombinasi dari 2 dimensi nilai yaitu keagamaan dan keagrariaan. Dimensi keagamaan meletakkan kegiatan perwakafan ini sebagai amal saleh \& tabungan atau investasi pahala para pelaku perwakafan untuk bekal di kehidupan akhirat kelak. Sedangkan dimensi keagrariaan memposisikan kegiatan perwakafan sebagai perwujudan partisipasi dari warga negara terhadap program yang sebenarnya tugas pemerintah yaitu penyediaan dan pengadaan tanah untuk prasarana peribadatan sosial yang sejalan dengan syariat agama Islam.

Peraturan perundang-undangan wakaf secara khusus mengatur dengan rigit tentang prosedur pelaksanaan wakaf tanah, termasuk mekanisme pengalihan status hak, atau dikenal dengan istilah tukar guling (ruislag) yang harus mendapat ijin tertulis dari Menteri Agama setelah mendapat rekomendasi dari BWI dengan prosedur yang sangat ketat. Namun, aturan yang rigit ternyata tidak serta merta dapat menutup titik-titik kerawanan dalam pelaksanaannya di lapangan. Karenanya untuk kepastian hukumnya dan perlindungan wakaf dari pemasalahan yang tidak diinginkan harus ada legalitas kepastian hukumnya yaitu dengan sertifikasi. $^{2}$

Beberapa aturan tentang wakaf tentunya dalam pelaksanaannya akan sangat berpengaruh dalam perwakafan khususnya wakaf tanah di Kalimantan Timur, sementara itu sebagian anggapan di masyarakat memahami bahwa wakaf lebih menitik beratkan nilai ibadah dan pada saat masyarakat mewakafkan tanah tidak akan ada kekawatiran atas segala resiko yang akan ada dikemudian hari. Walaupun wakaf memiliki dimensi nilai keagamaan dari dimensi yang lain kepastian hukumnya tetap harus ada.

Mengingat pentingnya legalitas wakaf ini maka peneliti tertarik untuk meneliti sejauh mana pelaksananaan sertifikasi wakaf di Kaltim. Dan dalam pelaksanaan sertifikasi wakaf tersebut bagaimanakah kendala-kendala di lapangan.

\section{RUMUSAN MASALAH}

Dalam konteks Indonesia, wakaf tanah telah diatur oleh PP No. 28 Tahun 1977 tentang Perwakafan Tanah Milik dan Permenag. No. 1 Tahun 1978 tentang Peraturan Pelaksanaannya. Dalam UUPA, secara tidak langsung wakaf tanah disebut dalam satu bagian 
tentang hak-hak tanah untuk keperluan suci dan sosial, meskipun tidak secara detail. Kemudian, sejak tahun 2004, peraturan perundang-undangan wakaf disempurnakan lagi melalui UU No. 41 Tahun 2004 tentang Wakaf dan peraturan perundangan turunannya. Sejak disempurnakannya pengaturan wakaf tentunya akan sangat berpengaruh terhadap pelaksanaan sertifikasi wakaf khususnya di Kaltim, karenanya peneliti ingin meneliti tentang pelaksanaan sertifikasi wakaf di Kaltim khususnya di Samarinda, Balikpapan dan Kutai Kartanegara (Kukar). Demi terfokusnya penelitian ini maka penulis merumuskan permasalahan sebagai berikut:

1. Bagaimanakah pelaksanaan sertifikasi tanah wakaf di Kalimantan Timur?

2. Apakah kendala-kendala yang dihadapi dalam pelaksanaan sertifikasi tanah wakaf di Kalimantan Timur?

\section{TUJUAN PENELITIAN}

Adapun yang menjadi tujuan dari penelitian tersebut adalah:

1. Untuk mengetahui pelaksanaan sertifikasi tanah wakaf di Kalimantan Timur.

2. Untuk mengetahui kendala-kendala dalam pelaksanaan sertifikasi tanah wakaf di Kalimantan Timur.

\section{METODE PENELITIAN \\ A. Jenis Penelitian}

Metode yang digunakan pada penelitian ini berdasarkan sifatnya merupakan penelitian yuridis empiris, yang bersifat kuantitatif dengan cara/metode kajian deskriptif analisis melalui penelitian lapangan dan bahan-bahan kepustakaan, yang berupa wawancara dengan pihak Kantor Kementerian Agama yang berkompeten dalam sertifikasi tanah wakaf dan Badan Pertanahan Nasional selaku institusi yang melakukan pendaftaran tanah wakaf.

Pendekatan yuridis empiris maksudnya, bahwa penelitian ini merupakan penelitian untuk mencari ketentuan-ketentuan peraturan yang mengatur tentang sertifikasi wakaf serta ditunjang dengan melihat keadaan yang ada di dalam praktek kemudian menganalisisnya, nantinya diharapkan dapat menentukan kebijaksanaan yang lebih baik untuk merumuskan peraturan-peraturan pengembangannya. Metode penelitian pendekatan deskriptif kuantitatif.

\section{B. Lokasi Penelitian}

Penelitian ini dilakukan di daerah Provinsi Kaltim dengan konsentrasi wilayah Kota Samarinda, Kota Balikpapan dan Kabupaten Kukar. Pemilihan lokasi ini didasarkan pertimbangan bahwa:

1. Kota Samarinda merupakan kota berpenduduk terbanyak dan terpadat di Kaltim, termasuk Kota Balikpapan juga Kab. Kukar adalah wilayah yang sangat berpotensi memiliki jumlah terbesar wakif di Kaltim;

2. Daerah selain tiga tempat di atas ada beberapa merupakan daerah baru/pemekaran sehingga sulit dijadikan parameter.

3. Dari berbagai wilayah di Kaltim dengan sampel tiga wilayah tersebut sudah dapat menggambarkan kondisi sertifikasi tanah wakaf dan sudah dapat dijadikan parameter wilayah lainnya di Kaltim. 


\section{Jenis dan Sumber Data}

Pada penelitian ini, jenis data yang digunakan bersumber pada data primer dan data sekunder, yaitu:

1. Data Primer, yaitu data yang diperoleh langsung dari sumber pertama. Data primer ini diperoleh melalui wawancara. Kaitannya dengan penelitian ini, wawancara dilakukan untuk menggali pelaksanaan sertifikasi wakaf di Kaltim, peneliti juga melakukan studi dokumetasi berupa pendataan sertifikasi wakaf di Kantor Kementerian Agama Wilayah Provinsi Kaltim, serta pelaksanaan pendataan sertifikasi di tiga wilayah yaitu, Kantor Kementerian Agama Kota Samarinda, Kantor Kementerian Agama Kota Balikpapan, dan Kantor Kementerian Agama Kab. Kukar. Sedangkan wawancara dilakukan kepada Kantor Pertanahan Kota Samarinda, Kantor Pertanahan Kota Balikpapan dan Kantor Pertanahan Kab. Kukar.

2. Data Sekunder, yaitu data yang diperoleh melalui studi kepustakaan, dimana sumber data dapat berupa dokumen-dokumen resmi, karya ilmiah, jurnal-jurnal penelitian ilmiah, artikel ilmiah, surat kabar, majalah maupun sumber tertulis lain yang ada hubungan dengan obyek penelitian. Data kepustakaan berupa perundang-undangan tentang wakaf, peraturan pelaksanaan perundang-undangan tentang wakaf serta peraturan lain yang berkaitan dengan sertifikasi wakaf.

\section{Teknik pengumpulan data}

Metode penelitian lapangan, menurut Gulo, pengumpulan data dilakukan untuk memperoleh informasi yang dibutuhkan dalam rangka mencapai tujuan penelitian. ${ }^{3}$ Teknik pengumpulan data yang dipilih tergantung pada faktor utama dan jenis data. Dalam penelitian ini metode pengumpulan data yang digunakan adalah :

1. Wawancara

Wawancara adalah cara untuk memperoleh informasi dengan bertanya langsung pada narasumber. Secara eksplisit, Khan dan Chanel dalam Soerjono Soekanto menyatakan bahwa wawancara adalah: "....... a specialized pattern of verbal interction-initiated for spesipic purpose, and focused on some specific content area, with onsequent elimination of extraneous material." 4

Wawancara dilakukan secara tidak terstruktur (opened interview), yakni dengan menggunakan panduan yang membuat garis besar dan dikembangkan dengan bebas selama wawancara berlangsung akan tetapi sebatas lingkup sertifikasi tanah wakaf secara mendalam. Bentuk wawancara ini (tak terstruktur), menurut Denzin dalam Mulyana, mirip dengan percakapan informal, dan dapat memperoleh informasi di bawah permukaan dan menemukan apa yang dipikirkan dan dirasakan orang mengenai peristiwa tertentu, disamping wawancara model ini bersifat luwes, dimana susunan pertanyaan dan kata-kata dengan bebas dapat diubah, menyesuaikan dengan kebutuhan dan kondisi pada saat wawancara. ${ }^{5}$.

Terkait dengan penelitian ini wawancara dilakukan dengan pihak-pihak yang terkait dengan sertifikasi wakaf di kalimanatan Timur, yaitu:

\footnotetext{
${ }^{3}$ W. Gulo, Metode Penelitian, Gramedia Widiasarana Indonesia, Jakarta, 2002, hal. 115.

4 M. Gazali Heldoep, Analisis Hambatan Pada Pelaksanaan Pembiayaan Modal Ventura, Tesis Magister Universitas Brawijaya, Malang, 2008, hal. 55.

5 Dedy Mulyana, Metodologi Penelitian Kualitatif, Paradigma Baru Ilmu Komunikasi dan Ilmu Sosial Lainnya, Remaja Rosda Karya, Bandung, 2002, hal. 181.
} 
a. Kantor Wilayah Kementerian Agama Provinsi Kaltim;

b. Kantor Kementerian Agama Kota Samarinda;

c. Kantor Pertanahan Kota Samarinda;

d. Kantor Kementerian Agama Kota Balikpapan;

e. Kantor Pertanahan Kota Balikpapan

f. Kantor Kementerian Agama Kab. Kukar;

g. Kantor Badan Pertanahan Kab. Kukar;

Melalui teknik wawancara ini, peneliti dapat menggali data selengkap-lengkapnya tentang bagaimana pelaksanaan sertifikasi wakaf di Kaltim.

\section{Dokumentasi}

Dokumentasi merupakan salah satu alat yang digunakan dalam penelitian kualitatif ini. Menurut Moleong, dokumen adalah setiap bahan tertulis ataupun film, yang tidak dipersiapkan karena adanya permintaan penyidik. ${ }^{6}$ Senada dengan Moleong, Arikunto menjelaskan bahwa dokumentasi adalah mencari data berupa catatan, transkrip buku, surat kabar, majalah, prasasti, notulen rapat, logger, agenda dan lain-lain. ${ }^{7}$

Dokumentasi penelitian difokuskan pada arsip pandataan sertfikasi wakaf. Sertifikasi wakaf ini dapat diketahui berapa jumlah wakif, jumlah wakaf yang sudah disertifikasi dan jumlah wakaf yang belum disertifikasi. Catatan-catatan mengenai sertifikasi nantinya diperlukan guna mendukung penelitian ini.

\section{E. Teknik Analisis data}

Proses analisa data merupakan usaha untuk menemukan jawaban atas pertanyaan yang diperoleh dari penelitian. Berkaitan dengan hal tersebut, diperlukan adanya proses penyederhanaan data, agar data-data yang diperoleh akan lebih mudah dibicarakan dan diinterpretasikan sehubungan dengan tujuan akhir adalah memperoleh data yang akurat.

Penelitian ini menggunakan pendekatan deskriptif kualitatif, dengan alasan agar dapat menggali informasi yang mendalam mengenai objek yang diteliti. Metode deskriptif sebagai prosedur pemecahan masalah yang diteliti berdasarkan fakta-fakta yang ada, sehingga tujuan dari metode deskriptif adalah untuk menggambarkan tentang suatu masyarakat atau kelompok tertentu atau gambaran tentang gejala sosial. ${ }^{8}$

Dalam penelitian ini menggunakan metode penelitian deskriptif kualitatif dengan alasan bahwa dalam penelitian ini berupaya menggali data, yaitu data berupa pandangan responden dalam bentuk cerita rinci atau asli. Selanjutnya dari data kualitatif yang diperoleh tersebut dirangkum dengan hasil wawancara. Kemudian responden bersama peneliti memberikan penafsiran, dan dokumen lainnya, yang kemudian digunakan untuk menyusun analisis dan deskripsi tentang pelaksanaan sertifikasi wakaf di Kaltim.

6. M. Gazali Heldoep, Analisis Hambatan Pada Pelaksanaan Pembiayaan Modal Ventura, Tesis Magister Universitas Brawijaya, Malang, 2008, hal. 56.

7. Arikunto, Prosedur Penelitian, Rineka Cipta, Jakarta, 1998, hal. 236.

8. Irawan Soehartono, Metode Penelitian Sosial, Bandung, 2002, hal 35. 


\section{HASIL DAN PEMBAHASAN}

\section{Pelaksanaan Sertifikasi Tanah Wakaf di Kalimantan Timur}

Selama melakukan penelitian di Kantor Kementerian Agama Provinsi Kaltim, peneliti mendapatkan data diantaranya tentang gambaran pelaksanaan sertifikasi tanah wakaf di Kaltim. Sebelum membahas permasalahan akan diuraikan mulai dari sejarahnya, kondisi dan pelaksanaan sertifikasi tanah wakaf di Kaltim.

Sebagaimana disebutkan dalam latar belakang permasalahan bahwa perwakafan dan sertifikasi tanah wakaf ternyata merupakan kombinasi dari 2 dimensi nilai yaitu keagamaan dan keagrariaan. Dimensi keagamaan meletakkan kegiatan perwakafan ini sebagai amal saleh \& tabungan atau investasi pahala para pelaku perwakafan untuk bekal di kehidupan akhirat kelak. Sedangkan dimensi keagrariaan memposisikan kegiatan perwakafan sebagai perwujudan partisipasi dari warga negara terhadap program yang sebenarnya tugas pemerintah yaitu penyediaan dan pengadaan tanah untuk prasarana peribadatan sosial yang sejalan dengan syariat agama Islam. Guna merealisasikan tujuan wakaf yang amat mulia, karenanya pengelolaan tanah wakaf menjadi satu hal yang sangat penting, selain juga mewujudkan tujuan dari wakaf itu sendiri, dan kepastian hukum tanah wakaf tersebut.

Bila dilihat sejarah wakaf, sejak datangnya Islam, wakaf dilaksanakan berdasarkan paham yang dianut mayoritas masyarakat Islam Indonesia, yaitu paham syafi'iyyah \& adat kebiasaan setempat. Pola pelaksanaan wakaf sebelum lahirnya peraturan undang-undang yang mengatur wakaf, masih menggunakan kebiasaan-kebiasaan keagamaan seperti mewakafkan tanah secara lisan dan atas dasar saling percaya kepada seseorang ataupun lembaga tertentu, tanpa melalui prosedur administratif karena dianggap sebagai suatu amalan ibadah semata dan harta wakaf merupakan milik Allah semata yang siapapun tidak akan berani menggugat. ${ }^{9}$

Jika selama ini masalah wakaf kurang intensif dibahas bisa jadi karena umat Islam mulai hampir melupakan kegiatan-kegiatan yang berasal dari lembaga perwakafan, selain itu adanya mismanagement dan korupsi dalam pengelolaan wakaf menyebabkan pamor dari lembaga wakaf makin terlupakan. Padahal, potensi wakaf sebagai salah satu instrumen dalam membangun sosial ekonomi kehidupan umat, sesungguhnya tidaklah dapat dipandang sebelah mata.

Wakaf telah memberikan kontribusi yang tidak sedikit di beberapa negara Islam lain. Dengan pengelolaan aset wakaf yang profesional, Mesir telah berhasil membangun sektor pendidikan dan medis dari dana hasil pengelolaan wakaf. Universitas Al-Azhar Cairo, rumah-rumah sakit, pendidikan dan pemberdayaan tenaga pendidik serta beasiswa bagi para mahasiswa dibiayai dari hasil wakaf. Bahkan sebagai gambaran di Amerika Serikat, sebuah negara sekuler terbesar telah mengelola wakaf dari warga muslim minoritasnya secara profesional oleh lembaga keuangan Islam, KAPF (Kuwait Awqaf Public Foundation). ${ }^{10}$

9. Leaflet Kementerian Agama Kantor Wilayah Provinsi Kalimantan Timur. $10 \mathrm{Ibid}$ 
Sesuai dengan ruang lingkup permasalahan, bahwa wakaf yang dimaksudkan dalam laporan penelitian ini difokuskan pada wakaf benda tidak bergerak, yaitu wakaf tanah. Pasal 15 Peraturan Pemerintah Republik Indonesia Nomor 42 Tahun 2006 tentang Pelaksanaan UU No. 41 Tahun 2004 tentang Wakaf menyebutkan bahwa, jenis harta benda wakaf meliputi:

a. Benda tidak bergerak;

b. Benda bergerak selain uang;

c. Benda bergerak berupa uang.

Benda tidak bergerak sebagaimana dimaksud dalam Pasal 15 PP No. 42 Tahun 2006 tentang Pelaksanaan UU No. 41 Tahun 2004 tentang Wakaf, hak atas tanah sesuai dengan ketentuan peraturan perundang-undangan baik yang sudah maupun yang belum terdaftar meliputi;

a. Bangunan atau bagian bangunan yang berdiri di atas tanah sebagaimana dimaksud pada huruf a;

b. Tanaman dan benda lain yang berkaitan dengan tanah;

c. Hak milik atas satuan rumah susun sesuai dengan ketentuan peraturan perundangundangan; dan

Benda tidak bergerak lain sesuai dengan ketentuan prinsip syariah dan Pasal 17 PP No. 42 Tahun 2006 tentang Pelaksanaan UU No. 41 Tahun 2004 tentang Wakaf, hak atas tanah yang dapat diwakafkan terdiri dari:

a. Hak milik atas tanah baik yang sudah atau belum terdaftar;

b. Hak guna bangunan, hak guna usaha atau hak pakai di atas tanah negara;

c. Hak guna bangunan atau hak pakai di atas hak pengelolaan atau hak milik wajib mendapat izin tertulis pemegang hak pengelolaan atau hak milik;

d. Hak milik atas satuan rumah susun.

Dalam konteks negara Indonesia, amalan wakaf sudah dilaksanakan oleh masyarakat muslim Indonesia sejak sebelum merdeka. Oleh karena itu pihak pemerintah telah menetapkan undang-undang khusus yang mengatur tentang perwakafan di Indonesia, yaitu UU No. 41 Tahun 2004 tentang Wakaf. Untuk melengkapi undang-undang tersebut, pemerintah juga telah menetapkan PP No. 42 Tahun 2006 tentang Pelaksanaan UU No. 41 Tahun 2004. Kalau dilihat secara keseluruhan maka peraturan-peraturan yang terkait dengan wakaf sebagai berikut:

a. UU No. 41 Tahun 2004 tentang Wakaf;

b. UUPA masalah wakaf dapat kita ketahui pada Pasal 5, Pasal 14 ayat 91 dan Pasal 49.

c. PP No. 42 Tahun 2006 tentang Pelaksana UU No. 41 Tahun 2004 tentang Wakaf.

d. Inpres Nomor 1 Tahun 1991 tentang Kompilasi Hukum Islam (KHI).

Beberapa ketentuan hukum perwakafan menurut KHI yang merupakan pengembangan dan penyempurnaan terhadap materi perwakafan yang ada pada perundang-undangan sebelumnya, antara lain: obyek wakaf, sumpah nazhir, jumlah nazhir, perubahan benda wakaf, pengawasan nazhir, peranan majelis ulama dan camat.

Pelaksanaan perwakafan terkait dengan sertifikasi tanah wakaf tidak terlepas dari peraturan-peraturan keagrariaan yang lain khususnya bila berbicara tentang sertifikasi tanah wakaf adalah tentang pendaftaran tanah. Sedangkan pendaftaran tanah wakaf dasar hukumnya meliputi (wakaf dari tanah negara), adalah: ${ }^{11 .}$ 
a. Undang-Undang Nomor 5 Tahun 1960;

b. PP Nomor 48 Tahun 1994 jo. PP Nomor 79 Tahun 1996;

c. PP Nomor 24 Tahun 1997;

d. PP Nomor 13 Tahun 2010;

e. PMNA/ KBPN Nomor 3 Tahun 1997;

f. PMNA/KBPN Nomor 3 Tahun 1999 Jo. PMNA/KBPN Nomor 9 Tahun 1999;

g. Peraturan KBPN RI Nomor 3 Tahun 2006;

h. Peraturan KBPN RI Nomor 4 Tahun 2006;

i. Keputusan Bersama Menag. RI dan KBPN Nomor 422/2004 dan Nomor 3/SKB/BPN/2004 tanggal 19 Oktober 2004;

j. SE KBPN Nomor 600-1900 tanggal 31 Juli 2003;

k. SE KBPN Nomor 500-049 tanggal 6 januari 2005.

Pembuatan sertifikat tanah wakaf berawal dari sebuah proses sertifikasi yang harus diawali dengan proses di Kantor Urusan Agama, untuk pembuatan AIW/APAIW. Pemohon datang ke Kantor Urusan Agama untuk pembuatan AIW/APAIW dengan membawa serta dokumen sebagai berikut: ${ }^{12}$

Sertifikat hak atas tanah (bagi yang sudah bersertifikat), surat-surat pemilikan tanah (termasuk surat pemindahan hak, surat keterangan warisan, girik dan lain-lain) bagi tanah hak milik yang belum memiliki sertifikat;

a. Surat pernyataan wakaf, asli dan photo copy rangkap;.

b. Surat keterangan dari lurah setempat yang diketahui camat bahwa tanah tersebut tidak dalam sengketa;

c. Susunan pengurus masjid atau mushala atau lainnya yang ditandatangani ketua dan diketahui oleh lurah setempat;

d. Mengisi formulir model WK dan WD;

e. Foto copy KTP wakif (yang berwakaf) apabila masih hidup;

f. Foto copy KTP para pengurus yang akan ditetapkan sebagai nadzir wakaf;

g. Foto copy KTP para saksi ;

h. Menyerahkan materai bernilai Rp. 6000,- (enam ribu rupiah) sebanyak 7 (tujuh) lembar;

i. Menandatangani Ikrar Wakaf (WI), bagi wakif yang masih hidup dan Akta Ikrar Wakaf (APAIW), setelah semua surat-surat lengkap dan diketik oleh petugas;

j. Membuat surat kuasa kepada PPAIW untuk proses pendaftaran ke BPN (blangko ada di KUA);

Sebagaimana disebutkan dalam Pasal 39 PP No. 42 Tahun 2006 tentang Pelaksanaan UU No. 41 Tahun 2004 tentang Wakaf bahwa,

(1)Pendaftaran sertifikat tanah wakaf dilakukan berdasarkan AIW atau APAIW dengan tata cara sebagai berikut:

a. Terhadap tanah yang berstatus hak milik di daftarkan menjadi tanah wakaf atas nama nadzir;

b. Terhadap tanah hak milik yang diwakafkan hanya sebagian dari luas keseluruhan harus dilakukan pemecahan sertifikat hak milik terlebih dahulu kemudian di daftarkan menjadi tanah wakaf atas nama nadzir;

12. Wawancara Kementerian Agama Provinsi Kalimantan Timur. 
c. Terhadap tanah yang belum berstatus hak milik yang berasal dari dari tanah milik adat langsung didaftarkan menjadi tanah wakaf atas nama nadzir;

d. Terhadap hak guna bangunan, hak guna usaha atau hak pakai di atas tanah negara sebagaimana dimaksud dalam Pasal 17 ayat (1) huruf b yang telah mendapatkan persetujuan pelepasan hak dari pejabat yang berwenang di bidang pertanahan di daftarkan menjadi tanah wakaf atas nama nadzir;

e. Terhadap tanah negara yang di atasnya berdiri bangunan mesjid, mushala, makam, didaftarkan menjadi tanah wakaf atas nama nadzir;

f. Pejabat yang berwenang di bidang pertanahan kabupaten/kota setempat mencatat perwakafan tanah yang bersangkutan pada buku tanah dan sertifikatnya.

(2)Ketentuan lebih lanjut mengenai tata cara pendaftaran wakaf tanah diatur dengan Permen. setelah mendapat saran dan pertimbangan dari pejabat yang berwenang di bidang pertanahan.

Pasal 38 PP No. 42 Tahun 2006 tentang Pelaksanaan UU No. 41 Tahun 2004 tentang Wakaf, untuk tata cara pendaftaran harta benda wakaf (harta benda wakaf tidak bergerak)

(1)Pendaftaran harta benda wakaf tidak bergerak berupa tanah dilaksanakan berdasarkan AIW atau APAIW;

(2) Selain persyaratan sebagaimana dimaksud pada ayat (1) dilampirkan persyaratan sebagai berikut:

a. Sertifikat hak atas tanah atau sertifikat hak milik atas satuan rumah susun yang bersangkutan atau tanda bukti pemilikan tanah lainnya;

b. Surat pernyataaan dari yang bersangkutan bahwa tanahnya tidak dalam sengketa, perkara, sitaan dan tidak dijaminkan yang diketahui oleh kepala desa atau lurah atau sebutan lain yang setingkat, yang diperkuat oleh camat setempat;

c. Izin dari pejabat yang berwenang sesuai ketentuan peraturan perundang-undangan dalam hal tanahnya diperoleh dari instansi pemerintah, pemerintah daerah, BUMN/BUMD dan pemerintah desa atau sebutan lain yang setingkat dengan itu;

d. Izin dari pejabat bidang pertanahan apabila dari sertifikat dan keputusan pemberian haknya diperlukan izin pelepasan/peralihan;

e. Izin dari pemegang hak pengelolaan atau hak milik dalam hal hak guna bangunan atau hak pakai yang diwakafkan di atas hak pengelolaan atau hak milik.

Bila tanah wakaf sudah terdaftar di Kantor Urusan Agama (KUA) dan sudah memenuhi AIW/APAIW maka selanjutnya adalah tanah wakaf menuju proses pendaftaran di Kantor Pertanahan. Adapun proses pendaftaran tanah wakaf di Kantor Pertanahan, persyaratan pendaftaran tanah wakaf adalah sebagai berikut:

1. Formulir permohonan yang sah dan ditandatangani pemohon/kuasa dengan materai cukup;

2. Surat kuasa bila dikuasakan;

3. Copy identitas pemohon/nadzir dan kuasa apabila dikuasakan yang telah dicocokkan dengan asli;

4. Bukti atas hak/garapan;

5. Akta Ikrar Wakaf/Surat Ikrar Wakaf;

6. Copy SPPT dan BBn;

7. Pertimbangan teknis pertanahan;

8. Lampirkan SSP/PPH;

Semua proses di Badan Pertanahan ini waktu penyelesaian selama 57 hari. 
Hasil penelitian menjukkan bahwa, ditemukan data tentang jumlah tanah wakaf di Kaltim, yang terdata terdiri dari beberapa wilayah kota/kabupaten. Dari data menunjukkan bahwa tanah wakaf di Kaltim, ada yang sudah bersertifikat dan ada yang belum bersertifikat. Yang belum bersertifikat tanah wakaf tersebut sudah terdaftar di Kantor Kementerian Agama kota/kabupaten dan bahkan sudah menjadi data tetap Kantor Kementerian Agama Provinsi Kaltim. Data temuan tersebut penulis lampirkan secara lengkap di lampiran laporan penelitian ini.

Data wakaf per lokasi tahun 2012 di Kaltim, yang ditemukan di lapangan oleh peneliti diolah yang selanjunya dibuat tabel disesuaikan dengan wilayah kabupaten/kota untuk mengetahui berapa jumlah tanah wakaf di Kaltim yang sudah bersertifikat maupun yang belum bersertifikat. Pengelompokan tabel diperlukan guna memudahkan menganalisa. Tabel ini didasarkan dari data yang diperoleh dari Direktori Kantor Kementerian Agama Wilayah Kaltim. Berikut data dari lapangan dikelompokkan berdasarkan kecamatan di masing-masing kabupaten/kota: ${ }^{13}$.

Tabel .1. Data Tanah Wakaf di Kab. Kukar.

\begin{tabular}{|c|l|c|c|c|}
\hline No. & Nama Kecamatan & $\begin{array}{c}\text { Jumlah Tanah } \\
\text { Wakaf }\end{array}$ & $\begin{array}{c}\text { Sudah } \\
\text { bersertifikat }\end{array}$ & $\begin{array}{c}\text { Belum } \\
\text { bersertifikat }\end{array}$ \\
\hline 1 & Tenggarong & 21 & 13 & 8 \\
\hline 2 & Loa Janan & 31 & 26 & 5 \\
\hline 4 & Muara Kaman & 23 & 7 & 16 \\
\hline 5 & Muara Muntai & 3 & 2 & 1 \\
\hline 6 & Loa Kulu & 19 & 37 & 5 \\
\hline 7 & Sebulu & 29 & 14 & 5 \\
\hline 8 & Muara Jawa & 19 & 9 & 28 \\
\hline 9 & Kota Bangun & 3 & 3 & 10 \\
\hline 10 & Muara Pahu & 7 & 7 & - \\
\hline 11 & Melak & 2 & 2 & - \\
\hline 12 & Barong Tongkok & 6 & 6 & - \\
\hline 13 & Long Iram & 74 & 6 & 8 \\
\hline 14 & Anggana & 5 & 16 & 62 \\
\hline 15 & Samboja & 22 & 5 & - \\
\hline 16 & Muara ulu & 5 & - & 22 \\
\hline 17 & Kembang Janggut & 2 & - & 5 \\
\hline 18 & Tabang & 25 & - & 2 \\
\hline 19 & Tenggarong sebrang & 3 & - & 25 \\
\hline 20 & Muara Badak & 7 & - & 7 \\
\hline 21 & Kenohan & 372 & 154 & 218 \\
\hline 22 & Marang Kayu & & & \\
\hline & Jumlah & 78 & - & - \\
\hline
\end{tabular}


Tabel 2. Data Tanah Wakaf di Kota Balikpapan

\begin{tabular}{|c|l|c|c|c|}
\hline No. & \multicolumn{1}{|c|}{ Nama Kecamatan } & $\begin{array}{c}\text { Jumlah Tanah } \\
\text { Wakaf }\end{array}$ & $\begin{array}{c}\text { Sudah } \\
\text { bersertifikat }\end{array}$ & $\begin{array}{c}\text { Belum } \\
\text { bersertifikat }\end{array}$ \\
\hline 1 & Balikpapan Utara & 126 & 52 & 74 \\
\hline 2 & Balikpapan Selatan & 58 & 34 & 24 \\
\hline 3 & Balikpapan Tengah & 74 & 47 & 27 \\
\hline 4 & Balikpapan Barat & 50 & 32 & 18 \\
\hline 5 & Balikpapan Timur & 31 & 17 & 14 \\
\hline & Jumlah & 339 & 182 & 157 \\
\hline
\end{tabular}

Tabel 3. Data Tanah Wakaf di Kota Samarinda

\begin{tabular}{|c|l|c|c|c|}
\hline No. & Nama Kecamatan & $\begin{array}{c}\text { Jumlah Tanah } \\
\text { Wakaf }\end{array}$ & $\begin{array}{c}\text { Sudah } \\
\text { bersertifikat }\end{array}$ & $\begin{array}{c}\text { Belum } \\
\text { bersertifikat }\end{array}$ \\
\hline 1 & Samarinda Ilir & 109 & 66 & 43 \\
\hline 2 & Samarinda Ulu & 56 & 32 & 24 \\
\hline 3 & Samarinda Utara & 95 & 76 & 19 \\
\hline 4 & Samarinda Seberang & 66 & 28 & 38 \\
\hline 5 & Sungai Kunjang & 49 & 33 & 16 \\
\hline 6 & Palaran & 82 & 69 & 13 \\
\hline & Jumlah & 457 & 304 & 153 \\
\hline
\end{tabular}

Tabel 4. Data Tanah Wakaf di Malinau

\begin{tabular}{|c|l|c|c|c|}
\hline No. & Nama Kecamatan & $\begin{array}{c}\text { Jumlah Tanah } \\
\text { Wakaf }\end{array}$ & $\begin{array}{c}\text { Sudah } \\
\text { bersertifikat }\end{array}$ & $\begin{array}{c}\text { Belum } \\
\text { bersertifikat }\end{array}$ \\
\hline 1 & Malinau Utara & 8 & 3 & 5 \\
\hline 2 & Malinau Kota & 18 & 5 & 13 \\
\hline 3 & Malinau Selatan & 1 & - & 1 \\
\hline 4 & Mentarang & 2 & - & 2 \\
\hline & Jumlah & 29 & 8 & 21 \\
\hline
\end{tabular}

Tabel 5. Data Tanah Wakaf di Paser

\begin{tabular}{|c|l|c|c|c|}
\hline No. & Nama Kecamatan & $\begin{array}{c}\text { Jumlah Tanah } \\
\text { Wakaf }\end{array}$ & $\begin{array}{c}\text { Sudah } \\
\text { bersertifikat }\end{array}$ & $\begin{array}{c}\text { Belum } \\
\text { bersertifikat }\end{array}$ \\
\hline 1 & Tanah grogot & 83 & 52 & 31 \\
\hline 2 & Pasir belengkong & 47 & 26 & 21 \\
\hline 3 & Kuaro & 56 & 22 & 34 \\
\hline 4 & Batu Sopang & 26 & 22 & 4 \\
\hline 5 & Long Kali & 56 & 39 & 17 \\
\hline 6 & Long Ikis & 44 & 26 & 18 \\
\hline 7 & Muara Komam & 33 & 24 & 9 \\
\hline 8 & Tanjung Aru & 33 & 10 & 23 \\
\hline & Jumlah & 221 & 157 & 378 \\
\hline
\end{tabular}


Tabel 6. Data Tanah Wakaf di Nunukan

\begin{tabular}{|c|l|c|c|c|}
\hline No. & Nama Kecamatan & $\begin{array}{c}\text { Jumlah Tanah } \\
\text { Wakaf }\end{array}$ & $\begin{array}{c}\text { Sudah } \\
\text { bersertifikat }\end{array}$ & $\begin{array}{c}\text { Belum } \\
\text { bersertifikat }\end{array}$ \\
\hline 1 & Nunukan & 22 & 12 & 10 \\
\hline 2 & Sembakung & 14 & - & 14 \\
\hline 3 & Sebatik & 21 & 15 & 6 \\
\hline & Jumlah & 57 & 27 & 38 \\
\hline
\end{tabular}

Tabel 7. Data Tanah Wakaf di Kota Bontang

\begin{tabular}{|c|l|c|c|c|}
\hline No. & \multicolumn{1}{|c|}{ Nama Kecamatan } & $\begin{array}{c}\text { Jumlah Tanah } \\
\text { Wakaf }\end{array}$ & $\begin{array}{c}\text { Sudah } \\
\text { bersertifikat }\end{array}$ & $\begin{array}{c}\text { Belum } \\
\text { bersertifikat }\end{array}$ \\
\hline 1. & Bontang Barat & 13 & - & 13 \\
\hline 2. & Bontang Utara & 23 & 3 & 20 \\
\hline 3. & Bontang Selatan & 7 & - & - \\
\hline & Jumlah & 43 & 3 & 33 \\
\hline
\end{tabular}

Tabel 8. Data jumlah tanah wakaf yang sudah bersertifikat dan yang belum bersertifikat di Kaltim

\begin{tabular}{|c|l|c|c|c|}
\hline No. & \multicolumn{1}{|c|}{ Kota/Kabupaten } & $\begin{array}{c}\text { Jumlah Tanah } \\
\text { Wakaf }\end{array}$ & $\begin{array}{c}\text { Sudah } \\
\text { bersertifikat }\end{array}$ & $\begin{array}{c}\text { Belum } \\
\text { bersertifikat }\end{array}$ \\
\hline 1. & Kab. Kukar. & 372 & 154 & 218 \\
\hline 2. & Kota Balikpapan & 339 & 182 & 157 \\
\hline 3. & Kota Samarinda & 457 & 304 & 153 \\
\hline 4. & Malinau & 29 & 8 & 21 \\
\hline 5. & Paser & 378 & 221 & 157 \\
\hline 6. & Nunukan & 57 & 27 & 38 \\
\hline 7. & Kota Bontang & 43 & 3 & 33 \\
\hline & Jumlah & 1676 & 899 & 777 \\
\hline
\end{tabular}

Setelah dijumlahkan data tanah wakaf dari tabel di atas, maka belum kesemuanya tanah wakaf di Kaltim yang telah terdaftar di Kantor Kementerian Agama telah bersertifikat. Belum disertifikasinya tanah wakaf di Kaltim, tentunya akan sangat berpengaruh terhadap kepastian jaminan hak atas tanah wakaf yang ada di Kaltim. Pentingnya sertifikasi tanah wakaf adalah disamping memberikan perlindungan kepada wakif berkaitan nilai ibadahnya, yang terpenting adalah untuk memberikan kepastian hukum dan perlindungan hukum kepada pemegang hak atas suatu bidang tanah, yang terdaftar agar dengan mudah dapat membuktikan dirinya sebagai pemegang hak yang bersangkutan. Untuk itu kepada pemegang haknya diberikan sertifikat sebagai surat tanda bukti haknya. Sebagaimana disebutkan jaminan kepastian hukum sebagai tujuan pendaftaran tanah meliputi, Pasal 19 UUPA, yaitu bahwa pendaftaran tanah diselenggarakan dalam rangka menjamin kepastian hukum di bidang pertanahan (rechtskadaster atau legal cadastre). Secara garis besar rincian tujuan pendaftaran tanah seperti yang dinyatakan dalam Pasal 3 Peraturan Pemerintah Nomor 24 Tahun 1997, yaitu:

a. untuk memberikan kepastian hukum dan perlindungan hukum kepada pemegang hak atas suatu bidang tanah, satuan rumah susunan hak-hak lain yang terdaftar agar dengan mudah dapat membuktikan dirinya sebagai pemegang hak yang bersangkutan. Untuk itu kepada pemegang haknya diberikan sertifikat sebagai surat tanda bukti haknya. Jaminan kepastian hukum sebagai tujuan pendaftaran tanah meliputi:

1) Kepastian status hak yang didaftar 
Artinya dengan pendaftaran tanah akan dapat diketahui dengan pasti status hak yang didaftar, misalnya Hak Milik, HGU, HGB, Hak Pakai, Hak Pengelolaan, Hak Tanggungan, Hak milik Atas Satuan Rumah Susun atau tanah wakaf.

2) Kepastian Subyek Hak

Artinya dengan pendaftaran tanah akan dapat diketahui dengan pasti pemegang haknya, apakah perseorangan (WNI atau orang asing yang ada di Indonesia), sekelompok orang secara bersama-sama, atau badan hukum.

3) Kepastian obyek hak

Artinya dengan pendaftaran tanah akan dapat diketahui dengan pasti letak tanah, batas-batas tanah, dan ukuran (luas) tanah.

b. Untuk menyediakan informasi kepada pihak-pihak yang berkepentingan, termasuk pemerintah, agar dengan mudah dapat memperoleh data yang diperlukan jika mengadakan perbuatan hukum mengenai bidang-bidang tanah dan satuan rumah susun yang sudah terdaftar. Untuk penyajian data tersebut dilaksanakan oleh seksi tata usaha pendafataran tanah Kantor Pertanahan kabupaten/kotamadya yang dikenal sebagai daftar umum, yang terdiri atas peta pendafataran tanah, daftar tanah, surat ukur, buku tanah dan dafatar nama.

c. Untuk terselenggaranya tertib administrasi pertanahan

Program pemerintah di bidang pertanahan dikenal dengan catur tertib pertanahan, yaitu tertib hukum pertanahan, tertib administrasi pertanahan, tertib penggunaan tanah, dan tertib pemeliharaan tanah dan kelestarian lingkungan hidup. ${ }^{14}$

\section{Kendala-Kendala Dalam Pelaksanaan Sertifikasi Tanah Wakaf di Kaltim}

Belum kesemuanya tanah wakaf yang terdaftar di Kantor Kementerian Agama Provinsi Kaltim bersertifikat, dikarenakan di lapangan pelaksanaan sertifikasi tanah wakaf mengalami kendala-kendala. Adapun kendala-kendala dalam pelaksanaan sertifikasi tanah wakaf tersebut bervariasi. Temuan di lapangan menunjukkan bahwa dari tiga sampel wilayah penelitian mengalami kendala yang berbeda-beda.

Hasil wawancara dengan Bapak Aliaman, S.Ag. kendala-kendala dalam sertifikasi tanah wakaf di Samarinda; ${ }^{15}$

"Pendaftaran sertifikat tanah wakaf di Kantor Pertanahan Samarinda sering mengalami kendala utamanya berkaitan dengan prosesnya yang sangat lama, yaitu pada proses pengukuran. Walaupun tanah wakaf berbasis sosial namun dalam pendaftaran sertifikat ke Kantor Pertanahan Samarinda diperlakukan sama dengan sertifikat lainnya, hanya untuk pendaftaran tanah wakaf tidak ada pembayaran pajak (PBB) sedangkan tanah wakaf yayasan tetap ada pembayaran pajak (PBB), karena wakaf yayasan berorientasi pada keuntungan, ini membawa dampak kurang diresponnya sertifikasi tanah wakaf dibandingkan dengan sertifikasi yang lain. Bahkan Kantor Kementerian Agama Kota Samarinda, juga pernah kehilangan berkas tanah wakaf di Kantor Pertanahan Samarinda, tetapi Kantor Pertanahan Samarinda tidak mau bertanggung jawab hingga Kantor Kementerian Agama Kota Samarinda harus mengeluarkan dana pengurusan ulang semua berkas yang ada".

Hasil wawancara dengan Bapak Wasiman, S.Ag. Dari Kantor Kementerian Agama Kab. Kukar, mengatakan bahwa, ${ }^{16}$

14 Urip santoso, Pendafatarn Dan Peralihan Hak atas tanah, Kencana, Jakarta, 2010, hlm. 20.

15 Wawancara dengan Bapak Aliaman, S.Ag. Kasie. Penyelenggara Syariah, Kementerian Agama Kota Samarinda, Senin, 25 Pebruari 2013. 
"Ada satu kondisi yang sangat mempengaruhi data wakaf di Kukar saat sekarang, karena pada tahun 2006 telah terjadi musibah kebakaran di Kantor Kementerian Agama Kukar. Kebakaran tersebut menyebabkan data-data wakaf habis termasuk sertifikat wakaf yang ada sebelum tahun 2006 tersebut, dari kejadian tersebut menjadikan kendala-kendala di Kementerian Agama terkait dengan pendataan wakaf di Kukar. Akibat kebakaran yang terjadi di tahun 2006, telah menghanguskan sejumlah sertifikat tanah wakaf yang keseluruhannya di simpan di Kantor Kementerian Agama Kab. Kukar., sehingga Kantor Kementerian Agama Kab. Kukar. harus melakukan pendataan ulang. Perlu sertifikasi ulang (pengurusan duplikat), diperlukan waktu dan dana yang sangat terbatas dimiliki oleh Kementerian Agama Kab. Kukar. Mengingat keterbatasan dana yang dimiliki Kementerian Agama Kab. Kukar maka mengakibatkan membebankan kewajiban sertifikasi merupakan kewajiban dari nadzir, karena kementerian tidak memiliki dana alokasi khusus untuk sertifikasi wakaf. Kendala-kendala lain dalam sertifikasi tanah wakaf di Kab. Kukar adalah permohonan nadzir sertifikasi wakaf ke Kantor Pertanahan Kukar sering tidak direspon dengan baik, walaupun sudah ada Surat Keputusan Bersama Menag. RI dan KBPN Nomor 422/2004 dan Nomor 3/SKB/BPN/2004 Tanggal 19 Oktober 2004 dari pusat tetapi belum dirasakan hasilnya oleh daerah Kukar. Bahwa kondisi tanah wakaf adalah tanah-tanah tidak produktif, pada saat tanah semakin produktif terkadang menjadi permasalahan, dengan digugatnya wakaf oleh ahli waris.

Hasil wawancara dengan Bapak H. Gazali, SH. mengatakan bahwa, ada beberapa kendala di lapangan dalam sertifikasi tanah wakaf di Kota Balikpapan, antara lain; ${ }^{17}$

"Kantor Kementerian Agama Kota Balikpapan pernah kehilangan 10 berkas tanah wakaf saat pengurusan sertifikat tanah wakaf di Kantor Pertanahan Kota Balikpapan. Pada saat pengukuran tanah wakaf dari AIW (terdata kemenag.) tetapi pada saat proses sertifikat di Kantor Pertanahan Kota Balikpapan, ukuran tanah luasannya menjadi berkurang diantaranya karena terkena fasilitas jalan umum. Dan pemerintah pada saat mengurangi tanah wakaf tidak ada pemberitahuan".

Dari semua proses pelaksanaan sertifikasi tanah wakaf, hasil penelitian menunjukkan bahwa dari tiga sampel yang menjadi obyek penelitian yaitu wilayah Kota Samarinda, Kota Balikpapan dan Kab. Kukar, ketiganya memiliki kendala-kendala dalam sertifikasi tanah wakaf yang hampir sama adalah pada saat menjalani proses pendaftaran di Kantor Pertanahan.

Peneliti saat melakukan penelitian di Kantor Pertanahan juga merasa terkendala, dari tiga sampel hanya satu dapat peneliti wawancara, dan hasil wawancara dengan Kantor Pertanahan Kab. Kukar, Bapak Sandy Adma subsie. pendaftaran tanah, tentang pendaftaran tanah wakaf beliau mengatakan bahwa, ${ }^{18}$

"Permohonan terakhir atas wakaf di Kukar terakhir tahun 2009. Sampai saat ini di Kutai Kartanegara belum ada permohonan wakaf dari Kementerian Agama Kab Kukar. Bahwa pihak Kantor Pertanahan Kukar adalah institusi yang pasif, selama dari Kementerian Agama Kab. Kukar tidak ada permohonan, maka Kantor Pertanahan Kab.

16. Wawancara dengan Bapak Wasiman, S.Ag., Kementerian Agama Kutai Kartanegara, Kamis, 28 Pebruari 2013.

17. Wawancara dengan Bapak H. Gazali, SH., Kasie. Penyelenggara Syari'ah, Kementerian Agama Balikpapan.

18. Wawancara dengan Bapak Sandy Adma Subsie. Pendaftaran Tanah, Kantor Pertanahan Kutai kartanegara. 
Kukar tidak ada program atau kewenangan berkaitan dengan sertifikasi tanah wakaf di Kukar".

Beberapa kendala yang dialami oleh Kantor Kementerian Agama dalam pelaksanaan sertifikasi tanah wakaf yang paling dominan adalah pada saat proses pendaftaran di Kantor Pertanahan, menunjukkan bahwa sesungguhnya Kantor Pertanahan sebagai ujung tombak pendaftaran tanah wakaf belum mampu mewujudkan pelayanan secara maksimal terhadap pendaftaran tanah. Sebagaimana prinsip yang dianut dalam pendaftaran tanah menurut Pasal 2 PP No. 24 Tahun 1997, Pendaftaran Tanah dilaksanakan berdasarkan asas sederhana, aman, terjangkau, mutakhir, dan terbuka. Khusunya terhadap asas terjangkau dimaksudkan keterjangkauan bagi pihak-pihak yang memerlukan, khususnya dengan memperhatikan kebutuhan dan kemampuan golongan ekonomi lemah. Pelayanan yang diberikan dalam rangka penyelenggaraan pendaftaran tanah harus bisa terjangkau oleh para pihak yang memerlukan. Bila tanah wakaf bersifat sosial yang tidak ada unsur keuntungan, seharusnya pendaftaran tanah wakaf punya kekhususan dibandingkan pendaftaran tanah yang lain. Bukan sebaliknya, permasalahan dana yang terbatas menjadi kendala utama proses pendaftaran di Kantor Pertanahan. Artinya bahwa asas sederhana ini belum terpenuhi secara maksimal bila dilihat dari pelaksanaan sertifikasi tanah wakaf di Kaltim.

\section{PENUTUP \\ A. Kesimpulan}

1. Pelaksanaan sertifikasi tanah wakaf di Kaltim, belum maksimal karena tanah wakaf yang terdaftar di Kantor Kementerian Agama belum kesemuanya bersertifikat;

2. Kendala-kendala dalam pelaksanaan sertifikasi tanah wakaf di Kaltim, adalah pada proses sertifikasi di Kantor Pertanahan, belum efektifnya Surat Keputusan Bersama Menag. RI dan KBPN Nomor 422/2004 dan Nomor 3/SKB/BPN/2004 Tanggal 19 Oktober 2004, biaya sertifikasi tanah wakaf yang diberikan oleh pemerintah masih terbatas, kurangnya pemahaman masyarakat terhadap wakaf, pengelolaan BWI yang belum maksimal.

\section{B. Saran}

1. Upaya sertifikasi tanah wakaf harus terus dilakukan oleh Kementerian Agama, kalau perlu dengan mekanisme masal, semacam prona.

2. Harus ada perhatian khusus terhadap keberadaan tanah wakaf, dengan koordinasi seluruh institusi yang keterkaitan dengan proses sertifikasi tanah wakaf.

\section{DAFTAR PUSTAKA}

\section{Daftar Literatur:}

a. Arikunto, Prosedur Penelitian, Rineka Cipta, Jakarta, 1998.

b. Dedy Mulyana, Metodologi Penelitian Kualitatif, Paradigma Baru Ilmu Komunikasi dan Ilmu Sosial Lainnya, Remaja Rosda Karya, Bandung, 2002

c. Gulo, W., Metode Penelitian, Gramedia Widiasarana Indonesia, Jakarta, 2002.

d. Heldoep, M. Gazali, Analisis Hambatan Pada Pelaksanaan Pembiayaan Modal Ventura, Tesis Magister Universitas Brawijaya, Malang, 2008.

e. Santoso, Urip, Pendafatarn dan Peralihan Hak Atas tanah, Kencana, Jakarta, 2010.

f. Soehartono, Irawan, Metode Penelitian Sosial, Bandung, 2002 


\section{Daftar Peraturan Perundang-Undangan:}

a. Undang-Undang Dasar Republik Indonesia Tahun 1945

b. Undang-Undang Nomor 5 Tahun 1960 Tentang Pokok-Pokok Agraria

c. Undang-Undang Republik Indonesia Nomor 41 Tahun 2004, Tentang Wakaf;

d. Peraturan Pemerintah Nomor 24 Tahun 1997, Tentang Pendaftaran Tanah

e. Peraturan Pemerintah Nomor 42 Tahun 2006 Tentang Pelaksanaan Undang-Undang Nomor 41 Tahun 2004 Tentang Wakaf;

f. Inpres Nomor 1 Tahun 1991 Tentang Kompilasi Hukum Islam (KHI)

\section{Daftar Internet}

a. Direktorat Jendral Bimbingan Masyarakat Islam, up date, Kamis 1 Maret 2012. 